\title{
LEGAL ISSUES OF ASSISTED REPRODUCTION- THE ALBANIAN PERSPECTIVE
}

\author{
Jonada Zyberaj \\ Lecturer at "Ismail Qemali" University of Vlore Albania \\ jonada2004@yahoo.com
}

Abstract

Assisted reproduction was provided in Albania as an alternative way of reproduction by the "Reproductive Health" law of 2002. This law is an attempt to give the possibility of access in new technologies of reproduction as surrogacy, heterologues and homologues artificial reproduction to infertile persons, but since the enter into force of this law no further provisions has been made to regulate the procedures and the consequences coming from its applicability. The issue of assisted reproduction is still a subject of debate and of legislative changes as it is still not completely regulated by law. in this important issue, constitutional rights of different individuals, different interests and family law principles are involved. Ethical, scientific and legal factors are those which should be taken into consideration by the legislator in the attempt to make further legislative provisions.

This paper analyses the few provisions on the assisted reproduction in the Albanian legislation. As a concept which implicates many institutions in different fields, the paper aims to give the Albanian perspective on different legal issues related to the topic. The reproductive right as human right and the state liability to ensure it through the health care system should be analyzed according to the Albanian Constitution and the European Court of Human Rights. The consequences of the ART on the family law is another legal issue with which the Albanian legislator has to deal with as the implementation of the techniques on assisted reproduction was not accompanied by the necessary changes in the provisions of family law. The legislations of different European countries which have the best experiences on the field will be put face to face and compared in order to give the best practices.

Key words: assisted reproduction, reproductive right, health care system, family law

\section{Introduction}

Bioethics and artificial reproduction as a part of it, is a field of a brief history. The legislative history of it is no more than 25 years old. But during its evolution more and more international conventions and positions by intergovernmental organizations are taken to regulate it.

National states have held different legal approaches on the field. Some of them have given themselves the opportunity to predict and to proceed to further developments on the field by adopting specific law and regulations. Other, feared from the further development that could come by the use of biotechnology, adopted rigid laws on the field and strong criteria for their application. A third approach is that of other countries that adopted laws in accordance to the social and technological flexibility.

Albania can be considered in the group of those countries who have no regulated this field. in 2002 the Albanian legislator decided to implement some provisions regarding the artificial reproduction in the Law on the "Reproductive Health". Incorporated with the other provisions of the reproductive health, the adoption of these provisions didn't give any impact in public. It seems that they were some "dumb" provisions standing there in the "Reproductive Health" law, until fertility clinics of private sector started to apply them. During the adoption of these provisions there were made no public debates on the ethical issues or in the legislative one that may rise during the implementation of them, as they were made in most of the states adopting such provisions. From 2002 until now no regulation is adopted in order to implement more specifically the provisions on the artificial reproduction. The fact that Albania has no regulation on the field makes the situation more uncertain especially according to the status of the donor, to the genetic rights of the child and especially to the criteria settled by the health providers for the applicants.

Albania is becoming a market of the artificial reproduction for citizens of other countries where the regulations exist and are even restrictive. This legislative gap is making the situation more and more uncertain. in the years ahead, when issues associated with the implementation of this few dispositions will arise, the Albanian legislator should be prepared in order to protect the individual rights implicated in this process and which may be threatened.

This paper aims to make a summary analysis of almost all the important issues relating to the application of artificial reproduction techniques. in the first part of the paper is analyzed the right to access in the artificial reproduction techniques 
as part of the procreation right. The implications of the artificial reproductive techniques with the principles and provisions of the family law are analyzed on the second part of the paper where through comparison with other jurisdictions is predicted which may be the changes in the Albanian family law. The third part of the paper has a short overview of the possibility of financing the artificial reproductive techniques by the Albanian health care system.

All the analyses is based in the approach of different European countries on the issues in order to have a complete picture on how this field is regulated. Artificial reproduction in Albania is now a fact and the reason for the treatment of this paper is to illustrate how a factual relationship should be safely incorporated and regulated by law.

\section{The right to procreate.}

The procreative right seen as a fundamental right would entail the person right to exercise it against all the other members of the society who had the obligation not to prevent it and the duty of the state to guarantee this right by ensuring the access in the procreation methods. Using such a right in the context of fundamental rights and freedoms include in the same context the assisted reproduction methods seen as methods which enable the realization of the right to procreate.

Even if from the theological concept procreation can be described as; "a marital act" it reflects important truths about human sexuality: that it is intrinsically and essentially ordered to procreation by its natural" (William, 2011), it is hard to find a definition of the right to procreate as it is seen as a widespread concept. Reproduction was seen as the creation of the biological descendents through the sexual intercourse but as Robertson emphasis that "this understanding of procreative liberty can be distinguished from reproductive roles played by persons who are not themselves attempting to acquire offspring of their own". (Robertson 1992)

Social changes are imposing a new concept of procreation; that of the right to use your reproductive material with the mean of reproduction without imposing rights and obligations.

Other authors distinguish the procreation from reproduction; According to Shanner ""procreative rights" refer more specifically to initiating a pregnancy and bringing children into the world. Procreative rights are thus literally rights to have children at all, as distinguished from reproductive rights that concern the timing and manner in which one reproduces...a right to make procreative decisions without governmental restriction or force; a right to procreate without discrimination by doctors or others; an equal right of infertile people to procreate when fertile people can do so..." (Shanner 1995) Such a distinction offered by Shanner presents as a procreative right the right to have access in the artificial reproduction techniques and it broadens the meaning of reproduction by providing it as a possibility given not only for infertile couples but even to singles or others who decide to procreate without a partner and when a sexual intercourse is not needed. As it is mentioned before it is quietly impossible to have a fixed concept of the right to procreate. in most of the cases this right is hided or interpreted under the right to have a family. Different international documents provide the right to have a family; as the Universal Declaration on Human Rights; Art 16 "Men and women of full age, without any limitation due to race, nationality or religion, have the right to marry and to found a family", Art 23 of the UN International Covenant on Civil and Political Rights "The right of men and women of marriageable age to marry and to found a family shall be recognized.", European Convention on Human Rights according to which "Everyone has the right to respect for his private and family life, his home and his correspondence. Men and women of marriageable age have the right to marry and to found a family, according to the national laws governing the exercise of this right." etc.

Even though the procreation right is not literally expressed in any international documents the jurisprudence of the courts have tried to fill the gap and they have been careful in interpreting cases brought before them on the issue by interpreting in the concept of family life even the right to access in the assisted reproductive techniques. (S.H v Austria 2011) (Dickson v. United Kingdom 2007)

The Albania Constitution doesn't explicitly provide any right to procreate but it provides in art 53 that "anyone has the right to marry and to have a family". The Constitution of Italy doesn't sanction any right to procreate but it is interpreted under art 30 and 31 "the right to have a family". Article 21 of the Constitution of Greece proclemates that "The family, being the cornerstone of the preservation and the advancement of the Nation, as well as marriage, motherhood and childhood, shall be under the protection of the State", by giving so a special attention to the family including here even the parenthood right. The Basic Law for the Federal Republic of Germany doesn't recognizes any right to procretate but it establishes the right to have a family under Art 6 "Marriage and the family shall enjoy the special protection of the state.

(2) The care and upbringing of children is the natural right of parents and a duty primarily incumbent upon them. The state shall watch over them in the performance of this duty". An interesting view is that of the Article 272 of the Constitution of 
the former Socialist Republic of Croatia of 1974 which provides the right of everybody to free decision about giving birth to children. This right was not recognized any more by the Constitution of the Republic of Croatia in 1990. (Kora 1998)

The lack of this provision in the States Constitution may occur as a result of their hesitation or fear to give liberty to procreation rights in the constitutional level in order to avoid any argument on the pro choice movement of different groups.

Although there is no constitutional provision protecting reproductive rights, Albania is still bound by some international conventions which guarantees family rights, non discrimination and the principle of the best interest of the child such as the Convention on the elimination of all forms of discrimination against women which guarantees the right of the women "... to decide freely and responsibly on the number and spacing of their children...". The Convention "On the Rights of the Child" entitles the child to know his/her origin and the right to be cared for by his or her parents (Art. 7).

Albania is a member of the Council of Europe and as such the decisions of the European Court of Human Rights are sources of law to which one can refer to interpret the right of reproduction. Although the Convention has not sanctioned explicitly such a right, the court through its interpretation has considered it as an expression of private and family life. According to the ECJ"...the right of a couple to conceive a child and to make use of medically assisted procreation for that purpose is also protected by Art 8 , as such a choice is an expression of private and family life...", protected by art 8 of the ECHR. (S.H vs Austria, 2011)

The provisions of the Albanian Law of 2002 are unclear and there is ambiguity in their interpretation. Even if art 30 of the law recognizes the purpose of the assisted reproduction as "the purpose of meeting the request of an individual or a couple to have a child", the whole interpretation of the dispositions related to assisted reproduction refer to it as an opportunity given to infertile couples who can't reproduce through the natural way. Moreover ART is admitted only for married couples, ruling out treatments for gay couples, single people, and women in menopausal age. Such a restrictive regulation derives from the interpretation of art 32, 34 and 40 which respectively defines the accessibility criteria to use artificial reproduction, assisted insemination and artificial in vitro fecundation.

\section{Art 32}

The techniques of reproduction are applied:

a) when an individual has reached the age to marry;

b) when the spouses have failed in attempts to have a child for a period of two years up to the moment when the transfer of the embryo and insemination is performed;

c) in the presence of a licensed specialist doctor;

c) only after the written consent has been received for each cycle by the interested individuals.

\section{Article 34}

Artificial insemination means using semen from a donor and injecting it into a woman. This is done when:

a) her spouse is infertile;

b) the donor is not the spouse of the woman.

\section{Article 40}

Artificial fecundation means the fertilization experimentally of female eggs with sperm of the man of a couple, outside the body of the woman. Participation in it is conditioned by the written permission of the woman who donates the eggs and the man who donates the sperm.

This is not an unexpected limitation since the Albanian legislation does not recognize homosexual marriages or homosexuals partnerships. Family is considered as an institution based or not in a marriage of two heterosexual individuals and their biological or adopted children. Given this is understandable such an arrangement of access on artificial reproduction techniques held by other states in Europe such as German, France and Italy which lead the right of procreation only with heterosexual couples.

Only a few legislations in Europe recognize the procreation rights of homosexuals or single persons by using the artificial reproductive technologies like Sweden and Spain which have recognized this right for lesbians and singles but not to gays (Swedish Act on Genetic Integrity, chapters 6 and 7) (Spanish law n. 14/2006 article 6/1) 


\section{The implications of the applicability of ART on the Family Law.}

The implementation of the provisions on the artificial reproduction will interfere with the provisions of the family law to the extent that they are related with the determination of paternity and the right of the donor to ask for parental responsibility against the right of the woman's husband to contest the presumed paternity. The Albanian Family Code of 2003 provides two forms of defining paternity;

- through presumption; for children born within a marriage or conceived during the marriage and born within 300 days from the day of the dissolution or the declaration void of the marriage if the mother has not being married during this period.

-through recognition of paternity for the children born out of wedlock; which may be applied in two forms (as a voluntary acknowledgment of paternity realized with the consent of the mother, and the judicial recognition of paternity). (Family Code, 2003)

As it can be seen by these provisions the Albanian Family Code links the definition of paternity with the possibility of the existence of blood ties between the offspring and the father. This presumption should fit in cases of homologues artificial reproduction when the husband of the women is also the donor, but in cases of heterologous artificial reproduction, where the donor is not the husband of the women, the situation gets complicated.

\section{Who should be the father of the child? Does the donor have the right to contest the presumed paternity?}

Neither the Family Code nor the "The reproductive health" law does not provide any clause on haw should paternity be determined in such situations. Many states have sanctioned another principle on defining paternity, the consent principle. This new form of determining paternity through the principle of consent will be applied when the father of the child is not his progenitor, because methods of artificial reproduction are realized through the donor participation. for children born by the application of the heterologous insemination, the father of the child should be determined according to the presumption principle. (HFEA, 2008)

By interpreting art 180 of the Albanian family Code; "A child born during a marriage is presumed to be the child of the husband", the legal father of the child born by heterologous insemination is presumed to be the husband of the mother. This means that even if the offspring is born by the application of heterologous insemination, the husband of the mother should be the presumed father of the offspring.

\section{But can the presumed father contest his presumed paternity?}

According to art 184 of the Albanian Family Code the presumed father can contest the presumed paternity of the child in one year from the date that the man had notice of the birth of the child. This provision gives the possibility to the husband of the women to contest his presumed paternity on bases of the offspring born by the application of heterologous insemination. The Albanian Family Code does not provide any exceptional provisions to be applied when the presumed father has given his consent for the application of these techniques as European countries do. According to the United Kingdom law, the husband who gave the consent for the artificial reproductive techniques can't himself bring a charge for contestation of paternity. (Vonk 2007)

European countries have the same approach even regarding to the donor of the sperm. The sperm donors are not treated as legal fathers, whereas husbands who consent to their wives' treatment are so regarded. (Schwenzer 2007) This mean that the donor can't ask for paternal responsibility as long as the women fertilized is married. He can't contest the presumed paternity by pretending the biological links between him and the offspring. According to the art 5 of the Spanish Law "On Art" the donor can't be subject to claim legal paternity under any circumstances. (Law 35/1988, art 5)

Such a claim can't be filed even according to our Family Law as it recognizes the right to contest the presumed paternity only to the presumed father, to the mother of the child and to the offspring. The donor is not legitimized to bring such a claim.

The continued expansion of the application of artificial reproductive technologies demands a reconsideration of new principles and new forms on defining paternity. The consent principle should be provided in the provisions of Family Law as a new principle to define paternity. The anonymity of the donor and the preservation of the offspring rights should be provided by law. Even though the situation in heterologous artificial reproduction is more complicated and the rights of some people are related to each other the legislator should take into consideration the best interest of the child which should be the clue principle to resolve any situation.

The financing of artificial reproductive techniques. 
Artificial reproduction is one of the forms of exercising the reproductive rights of individuals and a substantial part of the right of reproductive health. Seen in this perspective, states that provide artificial reproduction techniques as forms of reproduction in order to avoid infertility should fund these techniques within the health insurance scheme for as long they serve to the reproductive health of individuals.

Many European countries do not limit the implementation of artificial reproduction techniques as the possibility of reproduction of infertile couples, but they include also broader groups such as gay, lesbians or singles. Even if they differ in the access policies of the ART, most of the European countries have deemed infertility as a medical condition and their national policies fund all or some portion of infertility treatment. in compliance with the level of financing some of the European countries restrict access to the treatment by introducing eligible criteria such as age, marital status etc. for example; France has provided public funded from 2000 but limited it only to heterosexual infertile couples or couples who risk transmitting a disease. ( Council of Europe, Steering Committee on Bioethics (CDBI)) Germany, according to section 27/a of German Social Code V, an insured person may receive a reimbursement of $50 \%$ of the cost of the artificial reproduction techniques by meeting some criteria. in Italy there is reimbursement only for heterosexual couples and only in public health centers.

The law "On the health care in the Republic of Albania" provides the reproductive treatments as part of the health care scheme by providing it as reimbursable. The treatment of infertility is also provided as a reimbursable service at public health centers, but until today such techniques are performed only by private health centers and are financed fully by the individuals. The state inability to fund in private centers such services or to enable those in the public health centers has led to the fact that a significant part of infertile couples choose adoption instead of artificial reproduction methods.

In Albania there is still no legal regulation on the costs of artificial reproduction techniques and how to deal with them because so far these techniques not only are taking place in private clinics but also their performance fees are determined entirely by the clinics. The financial aspect of artificial reproduction techniques is of particular importance as it is not only related to the implementation or not of the right to reproductive health, but on the other hand the absence of such legal regulation also affects the growth of the phenomenon of "reproductive tourism ".

\section{Recommandation}

Artificial reproduction techniques and the concept of artificial reproduction itself are relatively lately provided by the Albanian legislation. The legislative history of these techniques in not more than 12 years old while in other states these techniques are being implemented for more than 25 years.

However, that is enough time to provide a more detailed legislation in order to regulate such a delicate field whose influence falls directly on the family structure. Although the provisions on the artificial reproduction are exhaustive and allow only the artificial reproduction among infertile spouses or those who suffer from genetically transmitted disease, many other criteria are left unspecified and in the physicians discretion.

The law of 2002 does not provide for what will be the position of the sperm donor. It doesn't even provide any obligation of physicians to preserve the anonymity of donors and of the recipients of the genetic material.

Unlike other legislations of the European countries which have provided the implications that the application of artificial reproduction may have on the family law, our legislation does not provide for what will be the position of the donor in relation to the offspring, whether he will be able to claim for parental responsibility or not.

Another issue which remains completely not regulated by the Albanian legislation is the number of the oocytes that can be implemented to achieve a pregnancy. Different jurisdictions have limited this number from 3 to 5 but there are others which do not provide an exhaustive number. It would be favorable if the legislator expressed this definition without leaving it entirely to the physicians' discretion.

It is just a matter of time that the implications of the application of the artificial reproduction will have in family issues to become courts litigations. in order to avoid family litigations on this issue, legislative provisions should have been taken to define by law the relations between three of the main actors of the ART; donor- offspring- beneficiary. It is also necessary to define the position of the husband of the women who performs heterologous artificial reproduction. Despite the fact that the family legislation presume that he is the father of the child, the law should provide the consent principle that is needed in the determination of parental responsibility.

The actual legislation let to the physicians the discretion in determining the accessibility criteria in these techniques. Elements such as, obtaining the consent of the husband of the woman, the anonymity of donors, administration of sperm 
banks and the couples right over the child, can't be left to medical practice. These elements should be regulated by law. It is the need for a legislative act which can give to couples, physicians and researchers a body of rules which attempt to reconcile the respect due to the human being, medical practice and necessary research.

\section{References}

[1] Albania Law Nr. 8876 dated 4 April 2002 "On Reproductive Health"

[2] Albanian Family Code, Law Number 9062 Adopted May 8, 2003, Art 170, 180, 181, 184-189

[3] Albanian Law Nr.10 107, 2009 "On the health insurance"

[4] Aleksandra KORA , 1998- Draft of the croatian act on medically assisted procreation - balancing procreative rights] Faculty of Law, Zagre UDK: 347.63:618.177-089.888.11 618.177-089.888.11:34 Pregledni rad Primljeno

[5] Council of Europe, Steering Committee on Bioethics (CDBI), supra note 15, at 20.

[6] Dickson v. United Kingdom, App. No. 44362/04, 46 Eur. H.R. Rep. 927, 945

[7] Human Fertilisation and Embryology Act 1990; 2008

[8] John A. Robertson; 1992, Noncoital Reproduction and Procreative Liberty pg 250

[9] M Vonk, 2007 "Children and their parent" A comparative study of the legal position of children with regard to their intentional and biological parents in English and Dutch law, ISBN 978-90-5095-732-8, p 155.

[10] Murphy, William F., Jr, 2011 Revisiting contraception: an integrated approach in light of the renewal of Thomistic virtue ethics..Article Type:EssayGeographic Code: 2011 StudiesISSN:0040-5639

[11] S.H v Austria App 57813/00 Judgment of 3 November 2011.

[12] Schwenzer, I. (ed) Tensions Between Legal, Biological and Social Conceptions of Parentage. (Intersentia: 2007) (CJ-FA (2008) 5), p 12.

[13] Shanner L 1995. "The right to procreate: When right claims have gone wrong" McGill Law Journal Vol 40 pg 826

[14] Spanish Law 35/1988 “ On ART” art 5

[15] Spanish law n. 14/2006 of May 26, on Assisted Human Reproduction Techniques, article 6/1

[16] Spanish Law on Assisted Reproductive Technology, Law 22/2006-Human Assisted Reproduction Techniques, LEY 14/2006, de 26 de mayo, sobre técnicas de reproducción humana asistida, Boletín Oficial del Estado, at http://www.boe.es/aeboe/consultas/bases_datos/doc.php?id=BOE-A-2006-9292

[17] The Albanian Constitution, 1998

[18] THE Constitution of Greece, 1957, last revision 2008

[19] The Constitution of the Italian Republic, 1947

[20] The European Convention on Human Rights, 1953

[21] The Swedish Genetic Integrity Act (2006:351) Chapters 6 and 7

[22] The United Nation, International Covenant on Civil and Political Rights, 23 March 1976

[23] The Universal Declaration of Human Rights (UDHR), Paris on 10 December 1948

[24] The Basic Law for the Federal Republic of Germany, 1949 